\title{
SANTA CLAUS SOLIDARITY FOR PALESTINE: A SEMIOTIC ANALYSIS OF THE MOHAMMAD TOROKMAN'S PHOTOJOURNALISM
}

\author{
Novan Jemmi Andrea \\ Department of Photography \\ Faculty of Recorded Media Arts, Institut Seni Indonesia Yogyakarta \\ Email: novan.jemmi@gmail.com
}

\begin{abstract}
Mohammad Torokman is a photojournalist with the Reuters News Agency. Torokman's photojournalism is chosen as "Picture of the Month: December" Reuters in 2017. The photo shows a picture of protesters dressed as Santa Claus throwing stones at the Israeli army when Palestinian protest against unilateral claims by the United States to make Jerusalem the capital of Israel. Torokman's photojournalism not only just evidence of a mere protest, but it has a message and a deeper meaning. This research discusses the denotation and connotation meaning of Torokman's photojournalism using the semiotics theory of Roland Barthes. This research is descriptive qualitative. This research concludes that Torokman's photojournalism has two meanings: solidarity and resistance. In the first level of analysis, Torokman's photojournalism shows the protestor's opposition to the Israeli army. On the second level of analysis shows the meaning of solidarity, which is shown through joint struggle without regard to religion and belief to maintain its territory in Jerusalem.
\end{abstract}

Keywords: photojournalism, icons, indexes, symbols, semiotics, solidarity

\section{INTRODUCTION}

Photojournalism is a journalism work that carries the task of presenting factual information in visual form. Accurate information in photojournalism can be in the form of events (phenomena) or current issues and still consider the news's values and their impact on society. Photojournalism is created by a photographer working in the mass media: a photojournalist. Thus, a photojournalist is a representative of the public to see an event with links with humanity's aspects.

From the journalism perspective, the public is always interested in various events worldwide, especially those related to global issues of humanity. One of the possibilities with high news value and concerns about humanity's global issues is the conflict over territorial sovereignty in Jerusalem involving Palestine and Israel. For a long time, the dispute triggered political diplomacy activities involving many countries, thus becoming one of the United Nations (U.N.).

On December 6, 2017, President Donald Trump said that the United States claimed Jerusalem as the Capital of Israel and caused the Jerusalem conflict to heat up again. There were large-scale protests in several areas in Jerusalem to reject unilateral claims from the United States. To 
this day, disputes in Jerusalem still occur and cause many fatalities.

The U.N. Security Council voted and signed a draft resolution urging the cancellation of President Donald Trump's claim to Jerusalem as the Capital of Israel. Fourteen members of the Security Council supported the draft resolution, while the United States was the only country that refused. Among the Security Council member countries that supported the draft resolution were Britain and France. Since the beginning, both countries expressed support for the resolution of conflict resolution in Jerusalem through negotiations between Palestine and Israel (Muhaimin, 2017).

Then, protests in Jerusalem came to the attention of the public, and journalistic products, including photojournalism, also came to the attention of international news channels. One of the photojournalism that contains protest in Jerusalem is Muhammad Torokman's photo. Torokman is a photojournalist who works for the Reuters News Agency. Torokman photographed a fragment of the Palestinian protest against Trump's policy that claimed Jerusalem as the Capital of Israel. Torokman's photo is full of iconic and symbolic elements that lead to broader meanings. In the context of the protest background, the visual component of the Torokman's photo shows a contradiction in the collective understanding of some parties about the conflict in Jerusalem.

So, this research will discuss the interpretation of photojournalism by Mohammad Torokman. The research question is 1) how the classification of sign and 2) how the denotation and connotation meaning in Mohammad Torokman's photo?

One theory that can be used to explore meaning in photojournalism is semiotics. This theory guides efforts to explore meaning through the process of identifying and reading sign relations. According to Budiman (Budiman, 2011), Charles Sander Peirce says that semiotics is another name for logic, a branch of philosophy. While Ferdinand de Saussure says that semiotics is a part of social psychology and semiotics (Saussure mention 'semiology') is a science that examines the life of signs in society.

Semiotics guide the reading and analysis of relations between one sign and another with certain classifications and their relation to specific contexts related to society's discourse. Therefore, in semiotics, the meaning of 'sign' has essential significance in the analysis. Pierce (Hawkes, 2003) (Budiman, 2011) explains that:

"A sign or representamen is 'something which stands to somebody for something in some respect or capacity'... A sign thus stands for something 
(its object); it stands for something to somebody (its interpretant); and finally, it stands for something to somebody in some respect (this respect is called it's ground)".

So, the meaning of a 'sign' or representamen is very dependent on someone who will interpret it.

Furthermore, Pierce classifies three categories of sign based on replaceable sign: icons, indexes, and symbols. An icon is a sign based on the similarity between the representamen and the object. An index is a sign that has a causal, actual, and general relationship to an item that can be a substance or a material object. And the symbol is an arbitrary sign that is usually based on conventions (Hawkes, 2003) (Budiman, 2011).

Semiotics study usually starts from the classify the signs and continues with the meaning at a certain level. The purpose is carried out along with reading the text; in this case, the text is in the form of photos (photojournalism). The reading is a negotiation process between practical experience with signs and conventions that make these signs have meaning.

Roland Barthes offers a way of examining and extracting meaning on two levels: denotation and connotation meaning. Denotation is the first level to explore the signs and their relation to reality then produce an explicit, direct, and specific meaning. Whereas connotation is the exploration of meaning at the second level, and shows the relationship between signifier and signified through the meaning of the second layer. This second layer's meaning is influenced by psychological aspects, emotions, and beliefs, but it remains conventional in which the signs are correlated with mental concepts. This second-level results in an expansion of meaning from the first level, which Barthes refers to as 'myth.' According to Barthes, myth encodes social and cultural values that are considered scientific (Piliang, 2003).

Besides semiotics theory, this research also suggests the theory of photojournalism to strengthen photojournalism as an object of research. According to Wilson Hick (Alwi, 2004), photojournalism is a combination of words and images that produce one communication unit when there are similarities between the background and the readers' social. When photojournalism is published, it is always equipped with the caption (information of the photo). The caption in photojournalism is intended to guide perception, so the context of information understood by the reader or viewer is not too biased. The caption contains $5 \mathrm{~W}+1 \mathrm{H}$ information (who, what, where, when, why, and how). That information will provide detailed information to readers or viewers so that the 
event's context is not perceived wildly. The documentative nature was inherent in photos, supported by professional ethics to record events as they are. Presentation of informative images are used as a guide to maintaining the credibility of photojournalism.

Photojournalism is not always an illustration to complete news or article, but it can stand alone as an information equivalent to news or articles. Photojournalism is a photo presentation that can stand alone as a visualization of news. Photojournalism can also complement and reinforce the message conveyed in the report (Yunus, 2010). So, the photojournalism that stands alone as information presents a recording of factual events with the power of visual structures that can be observed based on composition, photographic techniques, and the momentum of events that are enshrined.

\section{METHOD}

This research is qualitative descriptive research and based on facts about phenomena that occur in the community. Qualitative research aims to explain or describe a situation or phenomenon related to certain social phenomena of the research object. According to Ardial (Ardial, 2014), qualitative research believes that multiple realities affect the inductive flow of thought to produce conclusions in the form of explanations about interpretations that are entirely made by researchers. The descriptive method attempts to explore a phenomenon, clarify, and describe variables and units of research based on the appearance of data and facts that appear. Then, descriptive methods do not use or do not attempt to test hypotheses (Ardial, 2014).

The object of this research is Torokman's photojournalism. This photo was selected as 'Picture of the Month' in 2007 on Reuters News Agency. The 'Picture of the Month' is a collection of photographs chosen by photojournalists from Reuters representing important events throughout the world every month. This research is obtained and downloaded from Reuter's official website, which published the photos.

This research uses some steps to analyze the data based on semiotics analysis: First, identify the signs; Second, examine the signs' relation based on the second-level (connotation) signification systems; 3) Last, examine the signs' link found on the first-level (denotation) signification systems. The second level of analysis gives attention to the context and background of the events captured in the photo and their relationship to various conventions understood by the public. By 
exploring meaning according to context, this research will lead to a logical conclusion to this study.

\section{DISCUSSION}

On Tuesday, December 19, 2017, there was a protest from the Palestinians against the United States' unilateral recognition that claimed Jerusalem was the Capital of Israel in the West Bank city of Ramallah. In the demonstration, Palestinians brought various attributes as a symbol of their support for Palestinian sovereignty. As was often the case before, the action ended in clashes between demonstrators and the Israeli army. Like other protests, the protest ended with clashes between demonstrators and the Israeli military.

Several photojournalists covered the protest. They capture various moments and dramatic scenes from the beginning of the action to the clashes. One photojournalist who worked for Reuters News Agency named Mohammad Torokman succeed in capturing the picture of a demonstrator dressed in red as if he was throwing something towards a group of people in the distance, as shown in figure 1 . The Torokman's photo, which was equipped with a caption, spread to various parts of the world through mixed mass media quickly.

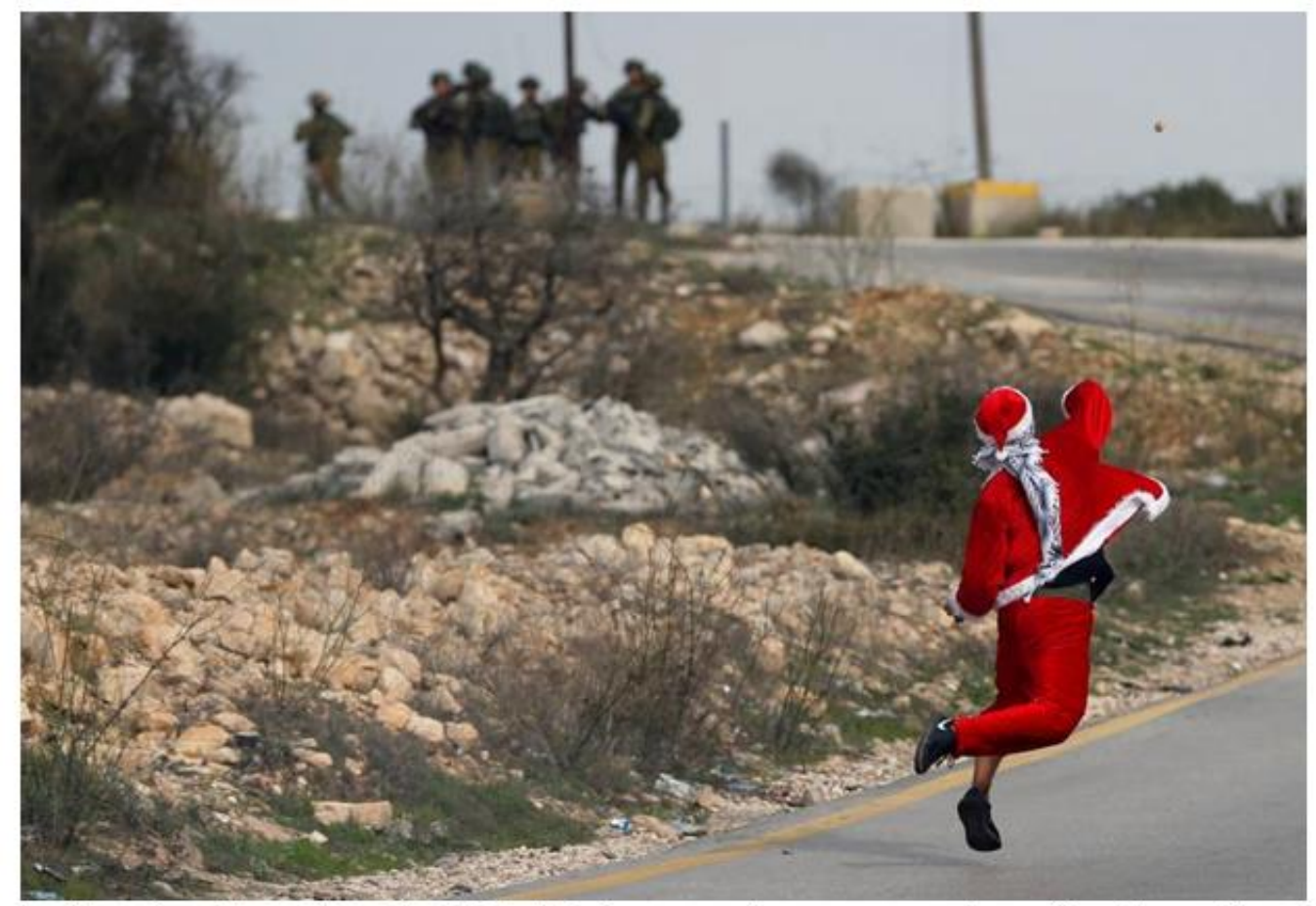

Reuters/Tuesday, December 19, 2017. A Palestinian demonstrator dressed as Santa Claus hurls stones towards Israeli troops during clashes at a protest against U.S. President Donald Trump's decision to recognize Jerusalem as the capital of Israel, near the West Bank city Ramallah. REUTERS/Mohamad Torokman

Figure 1. Photo by Mohamad Torokman with a caption published by Reuters. Source: (Reuters, 2017) 
Figure 1 represents the reality of a phenomenon that happened. This basic knowledge is identified from the caption that completes the publication. The caption or text that accompanies a photograph, as expressed by Barthes, functions as an anchorage (guide) that guides identification and leads to interpretation. The focus is to prevent the possibility of meaning out of context by each individual. The anchorage is the text function most often found in photojournalism (Barthes, 1977).

As a human-made product, a photograph indeed contains a particular obsession from the photographer. The subjectivity and personal motivation of the photojournalist must appear at the photo was made. However, as a journalistic work, photojournalism still has to strive for and prioritize objectivity. Then, the photojournalist is required to record the scene, even if what is recorded is a fragment of the entire protest's events. Artificial effects intentionally created by technological intervention or direct direction are minimal. In this case, the recording process is intended to maintain the credibility of the photographer and maintain public confidence in the facts contained in each photo produced and published.

Figure 1 shows that the reader's perception is maintained and directed to determine the background of the event that occurred with the caption. Torokman gives caption to his photojournalism as: " $A$ Palestinian demonstrator dressed as Santa Claus hurls stones towards Israeli troops during clashes at a protest against U.S. President Donald Trump's decision to recognize Jerusalem as the capital of Israel, near the West Bank city of Ramallah." The caption confirms that throwing stones at the Israeli army occurred during Palestinian protests in Ramallah, Palestine. The protest was a form of resistance against U.S. President Donald Trump, who claimed Jerusalem as the Capital of Israel.

Visual elements in photos are signs. Using the Barthes's semiotics approach, the signs in a photo influence the creation of a journalistic photo's meaning through two levels (denotation and connotation). Semiotics will first identify and classify the signs in the image.

At the first level, the denotation meaning, Torokman's photo is interpreted by referring to the relation of signs to explicit reality. According to Barthes, the first level of meaning is an iconic literal meaning. Photos are analogs of reality, "Thus can be seen the special status of the photographic image: it is a message without a code" (Barthes, 1977). Torokman's photo in the first level means an imitation or analogon of a reality of a protest or 
demonstration. Scenes of stone-throwing represented the protest carried out by a Palestinian dressed as Santa Claus to the Israeli army, which became a symbol of Israel's strength. As an analogon of reality, it means Palestinian protests and resistance against Israel and the United States related to Jerusalem's unilateral claims as to the Capital of Israel.

The main object or point of interest from Torokman's photo is someone who wears a red costume in the foreground and is in the focus area. Based on the relation of the signs attached to the point of interest, it looks like a teenager, wearing Nike shoes with casual models popular among young people. As a sign, Nike is an icon of a global shoe manufacturer and is well-known and loved by young people, especially casual models that are considered comfortable to wear in various situations.

The red costume attached to the object, complete with a distinctive hat, is also an icon of something known to the general public. In denotation meaning, it can be identified that the red costume is an icon of the figure of Santa Claus. It is also shown in the caption: A Palestinian demonstrator dressed as Santa Claus. Although the formation of Santa Claus is an imaginative figure, most people will have the same perception about his figure with all the attributes he wears. The concept of imagination about the figure of Santa Claus is known based on stories that are often heard. The story spread widely and later became a convention agreed by the relevant community about a Santa Claus figure.

Particularly for Christians, and generally, for people, Santa Claus is understood as a cheerful and kind person, where his presence is always expected, especially before the peak of the Christmas celebration. According to Hawken (Ulfa, 2018), Santa is a secularization of the figure of Saint Nicholas, a bishop who lived in the

Table 1. Classification of Signs in Torokman's Photojournalism

\begin{tabular}{|l|l|l|}
\hline No & Sign & Type \\
\hline 1 & Red costume & Icons \\
\hline 2 & Human body gestures in the foreground & Indexes \\
\hline 3 & Israeli army in the background & Symbols \\
\hline 4 & Floating stone & Indexes \\
\hline 5 & Scarf or kaffiyeh & Symbols \\
\hline 6 & Shoes & Icons \\
\hline 7 & Roads, grass, plants, rocks, poles & Icons \\
\hline
\end{tabular}

Source: Primary Data, 2020 
4th century A.D. in Myra. This small town was once part of the Roman Empire, now in the territory of Turkey. He is considered an angel who brings happiness because he always gives children gifts and helps those who need to be sincere. Figure 1 shows that the kind-hearted and still carrying happiness seems to be acting out of the ordinary and unusual. He seems to have just thrown something at the Israeli army. It can be identified from his gestures. The gesture is an index that refers to the action at a fraction of a second before and after. When throwing and shortly after the object is thrown is released from his hand.

Figure 1 shows that the stone he tossed still seemed to float. The stone is also an Index, which floated because it was previously thrown. And the one who threw was Santa Claus. In this scene, the figure is showing another broader message. It can be interpreted that he is trying to narrate the problem of the unilateral recognition of the United States of igniting a conflict that is harmful and might upset all parties, whether Muslims, Christians, or even Jews themselves. Then, Santa gets angry and gives a Christmas stone throw to the Israeli army.

Santa Claus becomes the central figure due to the narrow and sharp space (depth of field) photographic effect. He appears attractive with attributes such as kaffiyeh. He looked alone and became the point of interest of all visual elements in the photo. In denotation meaning, kaffiyeh is a cloth commonly used in various activities by the Palestinian people. If judging from the habits that occur from similar protest events, kaffiyeh is always used to cover the face not to get injured or hide identity. Kaffiyeh is a synonymous symbol with Arab countries and a characteristic that still emerges from every Palestinian protest against Israel. If it goes back to the 1930s, kaffiyeh becomes a symbol of Palestinian nationalism under the leadership of Yasser Arafat. Therefore, at the level of connotation meaning, kaffiyeh has a convention of importance as a symbol of Palestinian solidarity and struggle.

At this moment, Santa becomes the antithesis. Santa Claus, who is kind and always brings happiness to Christians, shows his resistance and courage against the Israeli army as a symbol of the country's strength and protection. He is standing alone using kaffiyeh. He is at the forefront of fighting directly with the Israeli army, supporting the Palestinian people who reject the unilateral claim of Jerusalem as the Capital of Israel. His presence and action showed the message that no matter what his religion, in Palestine, everyone fights for territorial sovereignty.

Durkheim (Jones, Bradbury, \& Boutillier, 2009) states that social solidarity is a form of solidarity in relationships 
between individuals and groups based on moral feelings and beliefs reinforced by emotional experience. Relations between Palestinian individuals and groups in conflict grow because of emotions and personal experiences. Difficulties in living due to the seizure of territory strengthen community solidarity even though they have different backgrounds. According to Hadinata (Hadinata, 2018), solidarity occurs when there are similar feelings. It manifests in the concept of 'us' so that the attitude of solidarity will not appear if the words 'I' and 'you' still appear in each individual. Such awareness enables solidarity to grow and stimulates collective actions to achieve a common goal. Like Santa Clause in Torokman's photo, he gets angry and doing protest alone to show his solidarity to his community. $\mathrm{He}$ transformed from a gentle figure into a ferocious model, taking the courageous role to face the Israeli army alone. The growing solidarity with these conditions inspired the people to join in the struggle together against Israeli occupation.

\section{CONCLUSION}

The relation of the signs present in Torokman's photo as the object of this research contains the meaning of resistance and solidarity. The stone-throwing Santa
Claus photojournalism by Torokman shows that the conflict that occurred in Jerusalem is a detrimental humanitarian conflict, and that action ignited people's struggles from any religious background. Demonstrators wearing Santa Claus costumes use the momentum of welcoming and celebrating Christmas to carry a specific message. The message is Santa's support for the Palestinian people's struggle and resistance to defend their territory from Israeli occupation.

In the level of connotation meaning, Torokman's photo shows solidarity meaning. Palestinians are often represented as Muslims. So the Santa Claus costume worn by protestors when protesting expresses the presence, solidarity, and support of Christians. A sense of belonging as an expression of solidarity arises through the symbol of Santa Claus, who represents Christians when fighting the Israeli army. Solidarity is demonstrated through the struggle between fellow humans with different background beliefs to fight certain groups' domination. Human solidarity becomes the most important thing to bring about peace. To realize these dreams, respect for the rights of human life must take precedence. 


\section{REFERENCE}

Alwi, A. M. (2004). Foto Jurnalistik: Metode Memotret Dan Mengirim Foto Ke Media Massa. Bumi Aksara: Jakarta.

Ardial. (2014). Paradigma dan model penelitian komunikasi. Jakarta: Bumi Aksara.

Barthes, R. (1977). Image, Music, Text. London: Fontana Press.

Budiman, K. (2011). Semiotika Visual: Konsep, Isu, dan Problem Ikonisitas. Yogyakarta: Jalasutra.

Hadinata, F. (2018). Mencari Kemungkinan Solidaritas Tanpa Dasar Universal: Telaah atas Pemikiran Etika Sosial Richard Rorty. Respons, 111-122.

Hawkes, T. (2003). Strukturalism and Semiotics. New York: Routledge.

Jones, P., Bradbury, L., \& Boutillier, S. L. (2009). PENGANTAR TEORITEORI SOSIAL (Edisi Revisi). Jakarta: Yayasan Obor Indonesia.

Muhaimin. (2017, Desember 19). Amerika. Retrieved from Sindonews.com: https://international.sindonews.com /berita/1266913/42/14-dari-15anggota-dk-pbb-tolak-statusyerusalem-as-penghinaan

Piliang, Y. A. (2003). Hipersemiotika: tafsir cultural studies atas matinya makna. Bandung: Jalasutra.

Reuters. (2017, Desember 19). Pictures. Retrieved from Reuters: https://www.reuters.com/news/pict ure/pictures-of-the-monthdecember-idUSRTX435LL
Ulfa, M. (2018, Desember 24). Sosial Budaya. Retrieved from Tirto: https://tirto.id/sejarah-sinterklasdalam-tradisi-natal-bukan-darikutub-utara-dcx7

Yunus, S. (2010). Jurnalistik Terapan. Bogor: Ghalia Indonesia. 